\title{
Flagellate and ciliate distribution in sediments of a lowland river: relationships with environmental gradients and bacteria
}

\author{
Björn Gücker*, Helmut Fischer
}

Leibniz-Institute of Freshwater Ecology and Inland Fisheries, Department Limnology of Lowland Rivers and Shallow Lakes, Müggelseedamm 301, 12587 Berlin, Germany

\begin{abstract}
It is generally assumed that protozoa are important predators of bacteria in the microbial food web, but limited data are available on protozoan abundance in streambed sediments. We investigated flagellate and ciliate abundance, community structure and spatial distribution in the shifting and stratified sandy sediments of a 6th order lowland river (River Spree, Germany) in relation to environmental gradients and bacteria. Flagellates and ciliates were quantified and identified using live observation and quantitative protargol staining techniques. Abundances (median and interquartile range) were 1900 cells $\mathrm{cm}^{-3}$ of benthic sediment (938 to 3363, $\mathrm{n}=104$ ) in flagellates and 148 cells $\mathrm{cm}^{-3}$ (29 to 363 ) in ciliates. Bodonids, colorless euglenids and hypotrich ciliates, predominantly Aspidisca cicada Müller, dominated the protistan community. Protistan abundance declined with increasing sediment depth in stratified sediments. A microaerophilic to anaerobic community occurred in deeper layers of these sediments. Aerobic bacterivorous protozoa prevailed in shifting sands. The prostistan community seemed to be structured by an interplay of factors, such as dissolved oxygen, light penetration, bacteria and sediment composition. Estimates using published grazing rates indicated that flagellate and ciliate densities were too small to control bacterial densities in these lowland river sediments.
\end{abstract}

KEY WORDS: Protists $\cdot$ Protozoa $\cdot$ Flagellates $\cdot$ Ciliates $\cdot$ Spatial distribution $\cdot$ Sediments $\cdot$ Lowland river $\cdot$ Microbial loop $\cdot$ Microbial food web $\cdot$ Microbial ecology

Resale or republication not permitted without written consent of the publisher

\section{INTRODUCTION}

Flagellates and ciliates are important components of marine and freshwater planktonic microbial communities in terms of biomass and function (Pomeroy 1974, Foissner et al. 1999, Laybourn-Parry \& Parry 2000). The importance of the microbial loop is well established in marine, planktonic environments; however, freshwater lotic ecosystems have received much less attention (Meyer 1994). Data sets on benthic flagellate and ciliate abundance are rare and contradictory (Foissner et al. 1992, Arndt et al. 2000, Findlay \& Sobczak 2000). Kemp (1990) infers that benthic flagellates and ciliates have the capacity to be important bacterivores, provided that they are abundant or graze at maximal rates. However, Findlay \& Sobczak (2000) conclude that protozoan (i.e. heterotrophic protists) grazing does not appear to control the production of hyporheic bacteria. Trophic interactions are highly complex (Wetzel 2001) and various trophic modes and feeding strategies exist within the protistan community (Foissner et al. 1995, Arndt et al. 2000, Sleigh 2000). Bacterial strategies against protozoan grazing (Caron 1987, Wright et al. 1995, Jürgens et al. 1999), mostly known from pelagic habitats, may also occur in the benthic zone.

Detailed information on protozoan abundance and spatial variation are prerequisites for the evaluation of their role in the microbial food web. Temperature, oxygen and food resources are generally assumed to be important factors affecting protozoan distribution and growth in aquatic environments (Fenchel 1987, Hausmann \& Hülsmann 1996, Wetzel 2001). Physical and 
chemical properties of sediments influence the distribution of protozoa that are sessile or surface-oriented (Hausmann \& Hülsmann 1996). For example, the quantitative and qualitative distribution of marine interstitial ciliates depends strongly on the size of the interstitial spaces (Fenchel 1987). However, in contrast to marine environments, no distinct and adapted interstitial ciliate community has been described in freshwater sediments. Interstitial-inhabiting species occur in various benthic habitats and even in the pelagic zone (Fenchel 1987, Foissner et al. 1999). Conversely, some flagellates groups that are typically adapted to move between sand grains are only rarely found in the pelagic zone's water column (Arndt et al. 2000).

However, limited data are available on protistan occurrence in river sediments (Arndt et al. 2000), even though these sediments have been identified as a habitat with high bacterial biomass and production (Fischer $\&$ Pusch 2001). We report flagellate and ciliate abundance and community structure in the shifting and stratified sediments of the lowland River Spree, Germany. We relate these data to current velocity, particulate organic matter (POM), particle size distribution, dissolved oxygen (DO) and bacteria, and analyze the distribution of protists using a principal component analysis (PCA). In addition, we evaluate protozoan grazing pressure on bacterial production and estimate potential grazing efficiencies using abundance data and published grazing rates. This is the first study to report ciliate and flagellate abundances and to estimate bacterial grazing potential in the sediments of a larger lowland river.

\section{MATERIALS AND METHODS}

Study site. Rising $480 \mathrm{~m}$ above sea level in the Lusatian Mountains at the Czech/German border, the River Spree flows through lowlands mainly consisting of porous glacifluvial sands that are partially covered with peat. After a course of $403 \mathrm{~km}$ with a mean slope of $0.1 \%$, it empties into the River Havel, a tributary of the River Elbe. Köhler (1994) and Sukhodolov et al. (1998) give detailed descriptions of the River Spree, its tributaries and lakes. Our study was located $\sim 40 \mathrm{~km}$ east of Berlin, in the lower River Spree, in a reach referred to as the 'Müggelspree'. During 2000, mean water depth was $1.4 \mathrm{~m}$, mean width of the main channel was $20 \mathrm{~m}$ and mean annual discharge was $9.9 \mathrm{~m}^{3} \mathrm{~s}^{-1}$. This 6 th order section represents a typical lowland river, characterized by a low longitudinal gradient of $0.015 \%$, a band of shifting sands located midstream, stratified sediments closer to the banks of the river, and high seston and phytoplankton loads. Despite high pelagic primary production, pelagic respiration accounted for only
$20 \%$ of the total community respiration in a previous study (Böhme 1994). In 1997 to 1998, sedimentary bacterial biomass was 6 to 22 times and sedimentary bacterial production 17 to 35 times higher than in the overlying water column (Fischer \& Pusch 2001).

Sampling. We extracted 1 sediment core $(6 \mathrm{~cm}$ inner diameter; Uwitech) on 4 equidistant stations (Stns a, b, c, d) along each of 3 transects, which were $250 \mathrm{~m}$ apart from each other, from the right bank to midstream. Sediments from all stations were sampled within a maximum time span of $11 \mathrm{~d}$ at 3 sampling periods in March, May/June and August 2000. After sampling, the cores were sealed in order to prevent leakage of interstitial water (Cleven 1999). The cores were then cut into layers of $1 \mathrm{~cm}$ thickness originating from the sediment's surface, 3.5 and $7 \mathrm{~cm}$ sediment depth. We took 1 subsample from each sediment layer for analyses of particle size, POM, bacteria and protists. Subsamples to be analyzed for bacteria and protists were stored on ice during transport to the laboratory. We measured current velocities $5 \mathrm{~cm}$ aboveground at each station immediately after sampling (current meter, MiniAir 2, Schildknecht, Messtechnik). For DO measurements, we extracted 1 sediment core at the station closest to the bank (Stn a) and the midstream station (Stn d) of each transect on 25 August 2002.

Particle sizes. Sediment subsamples were dried for $12 \mathrm{~h}$ at $105^{\circ} \mathrm{C}$ prior to analyses. Dry mass of the samples was $50.2 \pm 16.2 \mathrm{~g}(\mathrm{n}=104)$ and was sufficient for sieve analysis because of high homogeneity. Dry sieving was performed using a digital sieve shaker (Analysette 3 Pro, Fritsch) at an amplitude of $2.5 \mathrm{~mm}$ and an analysis time of 15 min. d10, d25, d50 and d75 particle sizes and the coefficient of particle size heterogeneity (sorting coefficient, So $=[\mathrm{d} 25 / \mathrm{d} 75]^{0.5}$ ) were calculated (Schwoerbel 1994). Pore volume was computed as the difference between the total volume of a sediment sample and the volume of its mineral matter, estimated from the mass of burnt samples using a mean density of the mineral matter of $2.5 \mathrm{~g} \mathrm{ml}^{-1}$.

Particulate organic matter. We determined POM as loss on ignition. Subsamples of $3 \mathrm{ml}$ were dried to constant weight at $105^{\circ} \mathrm{C}$ and subsequently burnt for $6 \mathrm{~h}$ at $550^{\circ} \mathrm{C}$ in order to determine POM as ash free dry mass (AFDM).

Dissolved oxygen. Immediately after the extraction of the sediment cores, we determined DO concentration in the pore water with an aluminum-coated DO microsensor (Microx TX Microoptode, PreSens) with a spatial resolution of $0.5 \mathrm{~cm}$. In each core, 3 replicated measurements were performed in the surface water, and in the 0.5-1, 2.5-3, 4.5-5 and 6.5-7 cm sediment layers.

Bacterial abundance and biomass. Bacteria were enumerated by the fluorescent count method of Porter \& Feig (1980), modified according to Brunke \& Fischer 
(1999). We fixed bacteria in $1 \mathrm{ml}$ sediment samples with $5 \mathrm{ml}$ of a sterile-filtered aqueous solution of $3.5 \%$ formaldehyde, $0.85 \% \mathrm{NaCl}$ and $1 \mathrm{mM}$ pyrophosphate $\left(\mathrm{Na}_{4} \mathrm{P}_{2} \mathrm{O}_{7} \times 10 \mathrm{H}_{2} \mathrm{O}\right.$, Sigma-Aldrich). After $10 \mathrm{~min}$ in a sonication bath (T $710 \mathrm{DH}$, Elma) at $60 \%$ power, a $0.2 \mathrm{ml}$ subsample was diluted $(1: 50, \mathrm{v}: \mathrm{v})$, mixed with 4',6-diamidino-2-phenylindol (DAPI, Sigma-Aldrich) to a final concentration of $10 \mathrm{mg} \mathrm{l}^{-1}$ and incubated for $40 \mathrm{~min}$ in the dark. Subsequently, the subsamples were filtered on black polycarbonate filters (pore size $0.2 \mu \mathrm{m}$, Whatman-Nuclepore). A minimum of 200 bacteria within at least 10 microscopic fields were directly counted on 1 filter per sample by epifluorescence microscopy (Nikon FXA Microphot, HBO 100 W, excitation 330 to $380 \mathrm{~nm}$, DM 400, BA 400, immersion objective CF N DIC Plan Achromate 100×). We estimated bacterial biomass and production using conversion factors of $22 \mathrm{fgC} \mathrm{cell}^{-1}$ and $1.2 \mathrm{fgC} \mathrm{cell}^{-1} \mathrm{~h}^{-1}$, respectively, determined by Fischer \& Pusch (2001) for the sediments of the River Spree.

Extraction. Low contents of detritus and fine sediments permitted the use of a differential sedimentation technique (Dye 1979, Bak \& Nieuwland 1989) to extract living flagellates and ciliates from the sediments, so that no density centrifugation (Wickham et al. 2000) was necessary. Sediment subsamples of $2 \mathrm{ml}$ were mixed with $8 \mathrm{ml}$ of sterile-filtered river water and gently shaken for $30 \mathrm{~s}$ in a $10 \mathrm{ml}$ test tube. After a sedimentation time of $15 \mathrm{~s}$, the supernatant was transferred into another tube. Recovery experiments with cultivated, surface-dwelling flagellates Bodo sp. and ciliates Holosticha sp. were performed according to Epstein (1995). Extraction efficiencies were calculated as the ratio between extracted protozoa and the number of protozoans transferred into protozoa-free sediments. We recovered $98 \pm 16 \%$ of the flagellates and $94 \pm 15 \%$ of the ciliates. Homogenized subsamples of the supernatant were used for flagellate and ciliate enumeration and taxonomical identification.

Flagellate abundance and taxa. Following Arndt et al. (2000), 12807 flagellates were analyzed alive by means of light microscopy. Of the supernatant, $20 \mu \mathrm{l}$ were transferred into a microchamber, consisting of a gridded microscope slide, sidewalls made of Vaseline, and a coverglass. Flagellates were counted and determined in 5 replicates with a microscope equipped with phase and differential interference contrast (Nikon FXA Microphot). Quantitative counts on genus to class level were performed with the aid of phase contrast at a magnification of 200x. Higher magnifications and differential interference contrast were additionally used for further taxonomical determinations.

Ciliate abundance and taxa. We applied the quantitative protargol stain (QPS) developed by Montagnes \& Lynn (1987) and modified by Skibbe (1994) for the enu- meration and determination of ciliates. Staining with protargol (i.e. albumose silver) can reveal many morphologic structures of ciliates, such as the nuclear apparatus, cilia, basal bodies, extrusomes and microtubuli, which have to be analyzed for taxonomical identifications (Foissner et al. 1999). We used $0.5 \mathrm{ml}$ subsamples of the supernatant, fixed the ciliates with Boin's fluid, filtered them on cellulose nitrate filters and embedded them in agar. The ciliates were then bleached with potassium permanganate, and stained with protargol and gold chloride. The stain was fixed with sodium thiosulfate. Subsequently, the cells were dehydrated with an isopropanole series and the filters were mounted on microscope slides with Canada Balsam. As up to half of the slides were of poor quality, we stained 5 aliquots of the supernatant and used the best 2 for further analyses. On these slides, by means of transmitted light microscopy, 5267 ciliates were counted and determined on genus or species level depending on their position in the agar and the quality of the stain.

Data analyses. Analyses of variance (ANOVA) (Underwood 1997) were used to test effects of sediment depth and distance to the bank on environmental variables and bacterial and protistan abundance. Multiple comparisons were made using Tukey's HSD test. A PCA (Jongman et al. 1995) was conducted for an ordination of the sampling positions based on protistan densities in order to explore distribution patterns of the protistan community. Data were $\log _{10}(x+1)$ transformed prior to analysis. Spearman rank and Pearson correlation analyses were carried out to reveal relationships between abundances of different flagellate and ciliate taxa and environmental variables and between various environmental variables, respectively. We used all 104 samples for the statistical analyses without averaging any data.

\section{RESULTS}

\section{Environmental variables and bacteria}

We characterized sediments by the current velocity $5 \mathrm{~cm}$ aboveground (Fig. 1), particle size distribution (Fig. 1), POM content, DO concentrations (Fig. 2) and bacterial abundance (Fig. 1).

\section{Current velocity}

Current velocities ranged from 0.03 to $0.44 \mathrm{~m} \mathrm{~s}^{-1}$ with a mean of $0.25 \pm 0.11 \mathrm{~m} \mathrm{~s}^{-1}$. Mean current velocities were highest above midstream sampling stations and decreased towards the bank (ANOVA and subsequent Tukey HSD test: $\mathrm{p}<0.001, F=9.82, \mathrm{n}=32$ ). 

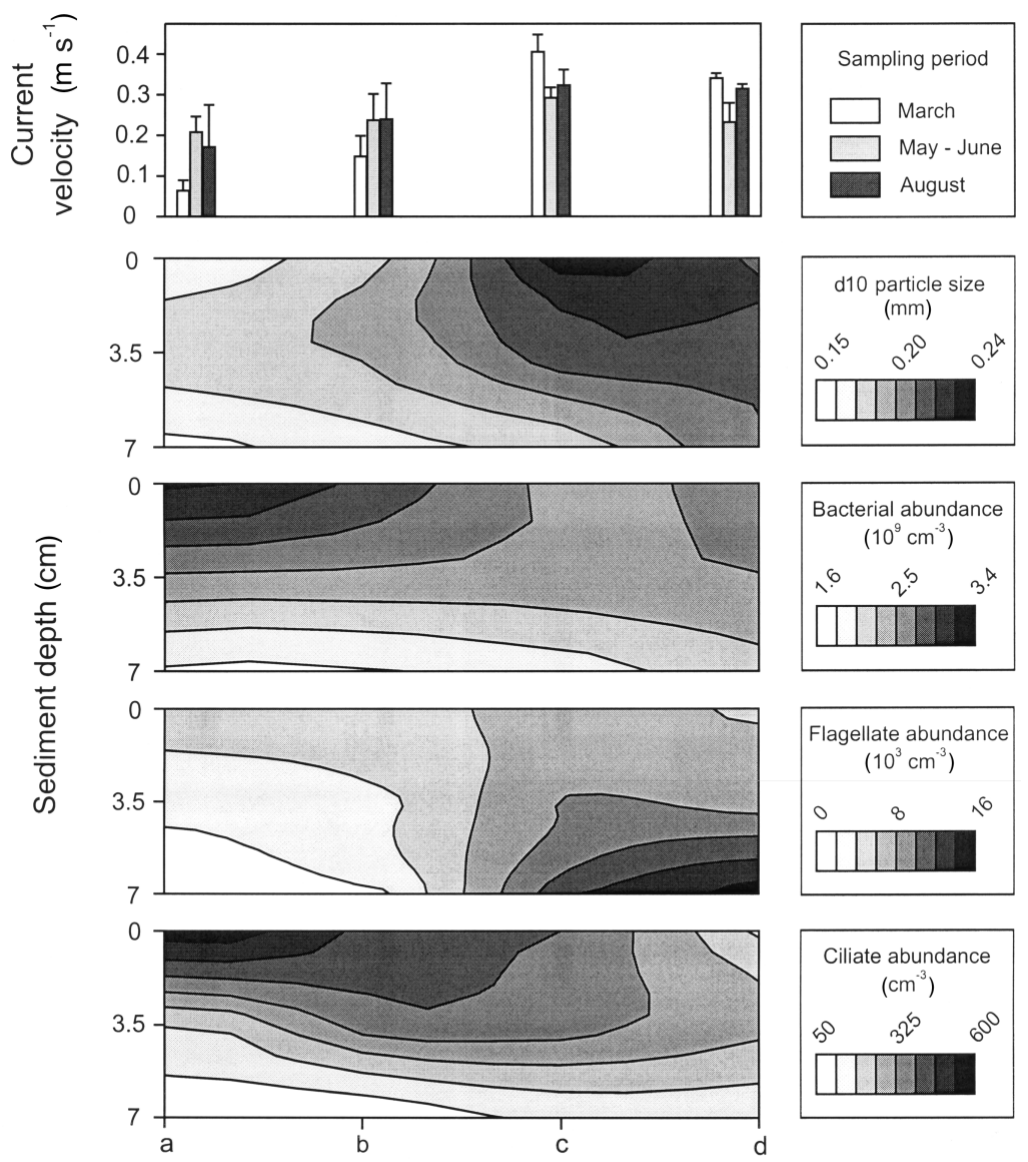

Sampling stations; $a$ = close to right bank, $d$ = midstream

Fig. 1. Current velocity $5 \mathrm{~cm}$ aboveground and spatial distribution of d10 particle sizes, and bacterial, flagellate and ciliate abundance. Arithmetic means ( $\mathrm{n}=9, \pm \mathrm{SD}$ for current velocities) and interpolations over 3 crosssections from the right bank to midstream
Particulate organic matter

Mean POM contents were $19 \pm 11 \mathrm{mg}$ AFDM $\mathrm{cm}^{-3}$ sediment and ranged from $<0.1$ to $60 \mathrm{mg}$ AFDM cm${ }^{-3}$. There was no apparent spatial distribution pattern. POM was negatively correlated with current velocity ( $\mathrm{p}<0.05, \mathrm{r}=-0.42, \mathrm{n}=36$ ) in surface sediments, but not in deeper sediment layers.

\section{Dissolved oxygen}

We measured very low DO concentrations in the pore water of nearshore surface sediments (Fig. 2). At these sites, deeper sediments layers were anaerobic. Pore water in midstream sediments was aerobic over the entire measured depth.

\section{Bacteria}

Bacterial abundances ranged between $2.15 \times 10^{8}$ and $4.48 \times 10^{9}$ cells $\mathrm{cm}^{-3}$. Mean bacterial abundance was $2.38 \pm 0.70 \times$ $10^{9}$ cells $\mathrm{cm}^{-3}$, corresponding to a mean bacterial biomass of $52.36 \pm 15.33 \mu \mathrm{g} \mathrm{C}$ $\mathrm{cm}^{-3}$. Bacterial production was estimated to be $2.86 \pm 0.84 \mu \mathrm{g} \mathrm{C} \mathrm{cm}{ }^{-3} \mathrm{~h}^{-1}$. Bacterial abundance decreased with sediment depth (ANOVA and Tukey HSD test: $\mathrm{p}<$ $0.001, F=20.78, \mathrm{n}=104)$.

\section{Particle sizes}

Sediments were homogenous with an average mean particle size (d50) of $0.46 \pm 0.24 \mathrm{~mm}$ and a mean coefficient of particle size heterogeneity of $0.64 \pm 0.12$. The mean pore volume was $39 \pm 5 \%$. d10 particle size, which was used as an indicator for finer sediment fractions, ranged from 0.05 to $0.40 \mathrm{~mm}$ with a mean of $0.19 \pm 0.06 \mathrm{~mm}$. Contents of finer sediment were highest in nearshore samples and decreased towards midstream (Fig. 1, low d10 particle size values indicate high contents of finer sediment) (ANOVA and Tukey HSD test: $\mathrm{p}<0.05, F=3.32, \mathrm{n}=104$ ). In the shifting sediments located midstream, contents of finer sediment were lower in surface sediments relative to deeper sediment layers (ANOVA and Tukey HSD test: $\mathrm{p}<0.05, F=3.49, \mathrm{n}=104)$. Contents of finer sediment at the sediment's surface were negatively correlated with current velocity ( $\mathrm{p}<0.05, \mathrm{r}=-0.41, \mathrm{n}=36$ ).

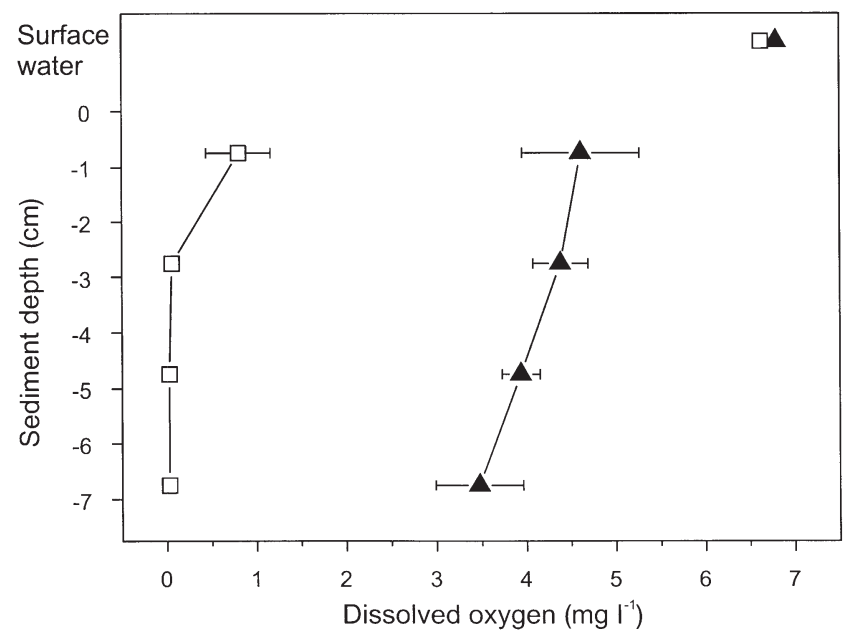

Fig. 2. Dissolved oxygen (DO) concentrations in nearshore $($ Stn $\mathrm{a}, \mathrm{\square})$ and midstream sediments (Stn d, $\mathbf{\Delta})$. Arithmetic means and SD over 3 transects. SD only shown where exceeding $0.05 \mathrm{mg} \mathrm{DO}^{-1}$ 

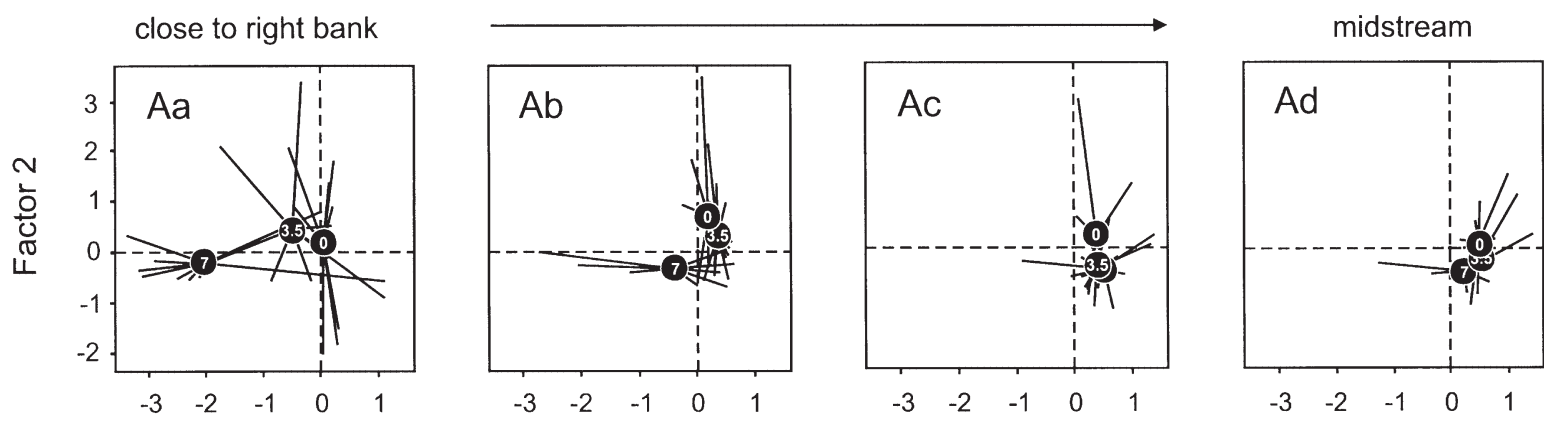

Factor 1

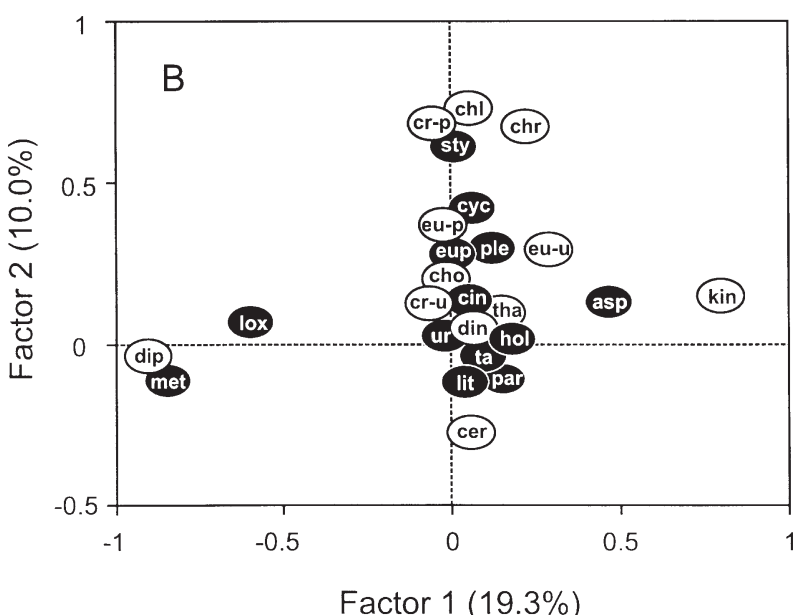

Spatial distribution of protistan abundance

Flagellate abundances ranged from 50 to 125700 cells $\mathrm{cm}^{-3}$, ciliate abundances from 0 to 1890 cells. Abundances (median and interquartile range) were 1900 cells $\mathrm{cm}^{-3}$ (938 to 3363, $\mathrm{n}=104$ ) in flagellates and 148 cells $\mathrm{cm}^{-3}$ (29 to 363) in ciliates. Flagellate abundance decreased with sediment depth in stratified sediments close to the bank (Stns a and b) (ANOVA and Tukey HSD test: $\mathrm{p}<0.05, F=4.04, \mathrm{n}=$ 52) and increased with sediment depth in shifting sediments midstream (Stns $\mathrm{c}$ and $\mathrm{d}$ ) (ANOVA and Tukey HSD test: $\mathrm{p}<0.05, F=3.45, \mathrm{n}=52$ ) (Fig. 1). Ciliate abundances generally declined with sediment depth in both sediment types (ANOVA and Tukey HSD test: $\mathrm{p}<0.001, F=8.77, \mathrm{n}=104$ ) and tended to increase towards the bank in upper sediment layers (Fig. 1).

\section{Distribution patterns of the protistan community}

Bodonids and colorless euglenids were the prevalent flagellate groups with 83 and $5 \%$ of the total abundance, respectively. Hypotrichs, predominantly Aspi-
Fig. 3. Principal component analysis (PCA) ordination plot of sampling positions based on protistan results. (A) Factorial scores of sampling positions grouped by sediment depth. Numbers indicate sediment depth in $\mathrm{cm}$. Circles identify centers of groups; a: $25 \%$ distance to bank, b: $50 \%$ distance, C: $75 \%$ distance, d: $100 \%$ distance (midstream). (B) Ordination of protozoan taxa. Correlation arrows are removed to improve clarity. Values in parentheses are the amount of variation explained by the principal component. Flagellate taxa (open ellipses): cer $=$ Cercomonadida, $\mathrm{chl}=$ Chlorophyta cho $=$ Choanoflagellata, $\mathrm{chr}=$ Chrysomonadea, $\mathrm{cr}-\mathrm{p}=$ pigmented Cryptomonada, $\mathrm{cr}-\mathrm{u}=$ unpigmented Cryptomonada, din = Dinoflagellata, dip = Diplomonadea, eu-p = pigmented Euglenida, eu-u = unpigmented Euglenida, kin $=$ Kinetoplas tida, tha = Thaumatomastigida. Ciliate taxa (filled ellipses): asp $=$ Aspidisca, cin $=$ Cinetochilium, cyc $=$ Cyclidium, eup $=$ Euplotes, hol $=$ Holosticha, lit $=$ Litonotus, lox $=$ Loxodes, met $=$ Metopus, par $=$ Paramecium, ple $=$ Pleuronema, sty $=$ Stylonychia, ta $=$ Tachysoma, ur $=$ Uroleptus

disca cicada Müller, dominated the ciliate community with $59 \%$ of the total abundance.

The first 2 factors of the PCA (Fig. 3) accounted for $29 \%$ of the total variability of the protistan community. However, 7 factors with eigenvalues exceeding 1, explained $62 \%$ of the total variability. Aerobic taxa with low tolerances towards anaerobic conditions or hydrogen sulfide (Berger et al. 1997) were positively correlated with Factor 1 (i.e. Kinetoplastida, predominantly Bodo spp. [factor load 0.81] and Aspidisca [0.46]). Anaerobic and microaerophilic taxa (Foissner et al. 1992, 1995, Lee et al. 2000) which negatively correlated with this factor were Diplomonadea (Factor load -0.83), Metopus (-0.82), and Loxodes (-0.57). Thus, Factor 1 seemed to depict a gradient of the DO preferences of protistan taxa (Fig. 3B). Phototrophic taxa and their predators (Foissner et al. 1991), like Chlorophyta (0.72), pigmented Cryptomonada (0.70), Chrysomonadea (0.69) and Stylonychia (0.61) had high positive correlations with Factor 2. Bacterivorous and omnivorous taxa did not correlate with this factor. Therefore, Factor 2 separated directly or indirectly light-dependent protistan taxa from taxa whose distribution is independent of light (Fig. 3B). In the PCA ordination, which was separately plotted for the 4 
sampling stations on the transects (Fig. 3A), the protistan community of nearshore sampling stations differed between sediment depths (Fig. 3Aa). Deeper sampling positions were dominated by microaerophilic and anaerobic taxa, whereas auto- and mixotrophic taxa predominantly occurred in surface sediments. This vertical gradient disintegrated towards midstream. Autoand mixotrophic taxa as well as microaerophilic and anaerobic taxa were rare, whereas aerobic bacterivores were found in all sampled sediment depths of midstream sampling stations. Midstream sampling positions of different sediment depths (Fig. 3Ad) had a similar community structure.

\section{Relationships between protozoan abundance and environmental variables}

Abundances of bacterivorous, aerobic flagellates and ciliates positively correlated with bacterial numbers (Tables 1 \& 2), both in the stratified and in the shifting sediments of the River Spree. In stratified sediments, negative correlations with POM contents and positive correlations with d10 particle sizes were found. Abundances of microaerophilic and anaerobic ciliates in this sediment type were negatively correlated with d10 particle sizes (i.e. a positive correlation with contents of finer sediment) and bacterial numbers. Highest abundances of the most frequent and abundant flagellate and ciliate genera (Bodo and Aspidisca, respectively) generally occurred at medium contents of finer sediment (Fig. 4). There were no relationships between other parameters of the particle size distribution (i.e. d25, d50 and d75 particle sizes, and So) and protozoan abundances.

\section{DISCUSSION}

Protists have rarely been included in studies of streambed sediments and the few previous studies concentrated on either the quantification of species numbers or absolute numbers. Protozoan community structure has generally been ignored. In a first study, Sleigh et al. (1992) analyzed both protozoan abundance and community structure in several chalk streams. In this study, we studied the flagellate and ciliate community of the sediments of a larger lowland river with high spatial and taxonomical resolution on a quantitative basis and characterized environmental variables that influence protozoan distribution.

Running waters that lack an expanded, hydrological connected hyporheic zone accommodate most of their protozoan abundance on and in their surface sediments (Baldock \& Sleigh 1988, Packroff \& Zwick 1998). From these types of sediment, high protozoan abundances were reported (Table 3). A microaerophilic to anaerobic protozoan community, poor in abundance

Table 1. Spearman rank correlation coefficients between flagellate abundance and particulate organic matter (POM), d10 particle size and bacterial abundance in the sediment samples $(\mathrm{n}=104)$. Levels of significance are ${ }^{*} \mathrm{p}<0.05,{ }^{* *} \mathrm{p}<0.01,{ }^{* * *} \mathrm{p}<0.001$, ns: not significant

\begin{tabular}{|c|c|c|c|c|c|c|c|c|}
\hline & \multicolumn{4}{|c|}{ - Stratified sediments } & \multicolumn{3}{|r|}{ - Shifting sediments } & \multirow[b]{2}{*}{ Bacteria } \\
\hline & $\mathrm{n}$ & POM & d10 particle size & Bacteria & $\mathrm{n}$ & POM & d10 particle size & \\
\hline Kinetoplastida & 45 & $-0.36^{* *}$ & $0.53^{* * *}$ & $0.55^{* * *}$ & 52 & ns & ns & $0.61^{* * *}$ \\
\hline Euglenida, pigmented & 26 & ns & ns & ns & 21 & ns & ns & ns \\
\hline Euglenida, unpigmented & 31 & ns & ns & $0.43^{* *}$ & 32 & ns & ns & $0.53^{* *}$ \\
\hline Cryptomonada, unpigmented & 14 & ns & $0.57^{*}$ & $0.80^{* *}$ & 13 & ns & ns & ns \\
\hline$\sum$ Flagellates, aerobic, bacterivorous & 47 & $-0.35^{*}$ & $0.50^{* * *}$ & $0.60^{* * *}$ & 52 & ns & ns & $0.63^{* * *}$ \\
\hline$\sum$ Flagellates, auto- and mixotrophic & 37 & ns & ns & $0.31^{*}$ & 31 & ns & ns & ns \\
\hline
\end{tabular}

Table 2. Spearman rank correlation coefficients between ciliate abundance and particulate organic matter (POM), d10 particle size and bacterial abundance in the sediment samples $(\mathrm{n}=104)$. Levels of significance are ${ }^{*} \mathrm{p}<0.05,{ }^{* *} \mathrm{p}<0.01,{ }^{* * *} \mathrm{p}<0.001$, ns: not significant

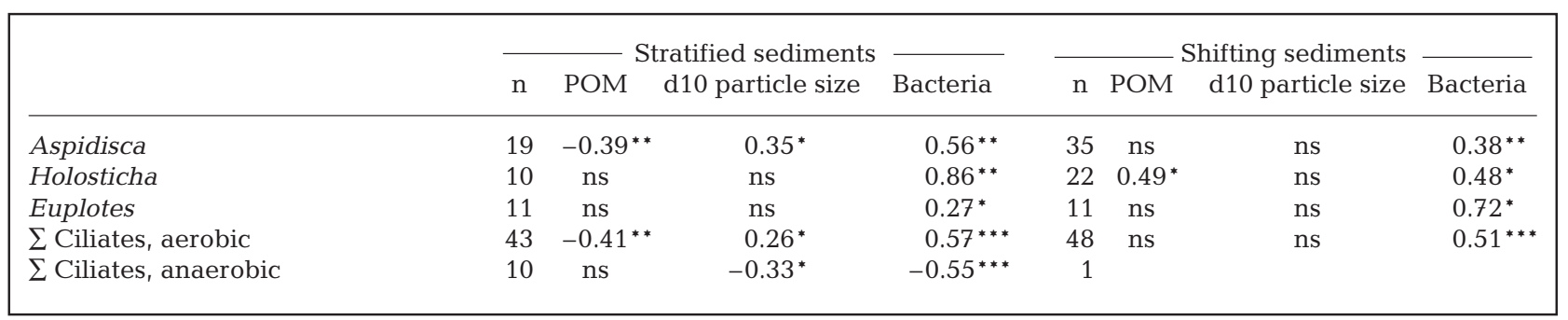


and diversity, occurred in deeper sediment layers (Packroff \& Zwick 1998). Increases in protozoan abundance down to $40 \mathrm{~cm}$ depth were found in streams and rivers with deep, oxygen-saturated hyporheic zones (Schmid-Araya 1994, Eisenmann et al. 1998). However, low overall protozoan abundances were reported from this type of running waters (Table 3). Sediment structure is the obvious reason for that, as it affects pore volume and particle surface area, which are the key descriptors of habitat space for suspended and surface-associated protists. Furthermore, sediment structure influences both hydrological exchange processes (Pusch et al. 1998) responsible for nutrient availability and protozoan motility in the sediments (Fenchel 1987). The middle-sandy sediments of the River Spree represented an intermediate position in the described continuum, both in abundance and vertical abundance distribution (Table 3). Protistan abundance decreased with sediment depth in the stratified sediments close to the bank, but the depth distribution of ciliates became more homogenous towards midstream. Flagellate abundance even increased with sediment depth in the shifting sediments located midstream (Fig. 1). This transition corresponded with the taxonomical shift of the community. We detected a vertical gradient in the protistan community structure at sampling positions close to the banks. This vertical gradient disintegrated towards midstream, where aerobic bacterivores dominated in all sediment depths.

The surface dimensionality of the substratum (Ricci 1989) and the mean particle size of sediments (Fenchel 1987) are important to surface-oriented and sediment-inhabiting protistan communities. In our study, the content of finer sediment was the most important variable of the particle size distribution for the distribution of protozoan abundances. In stratified
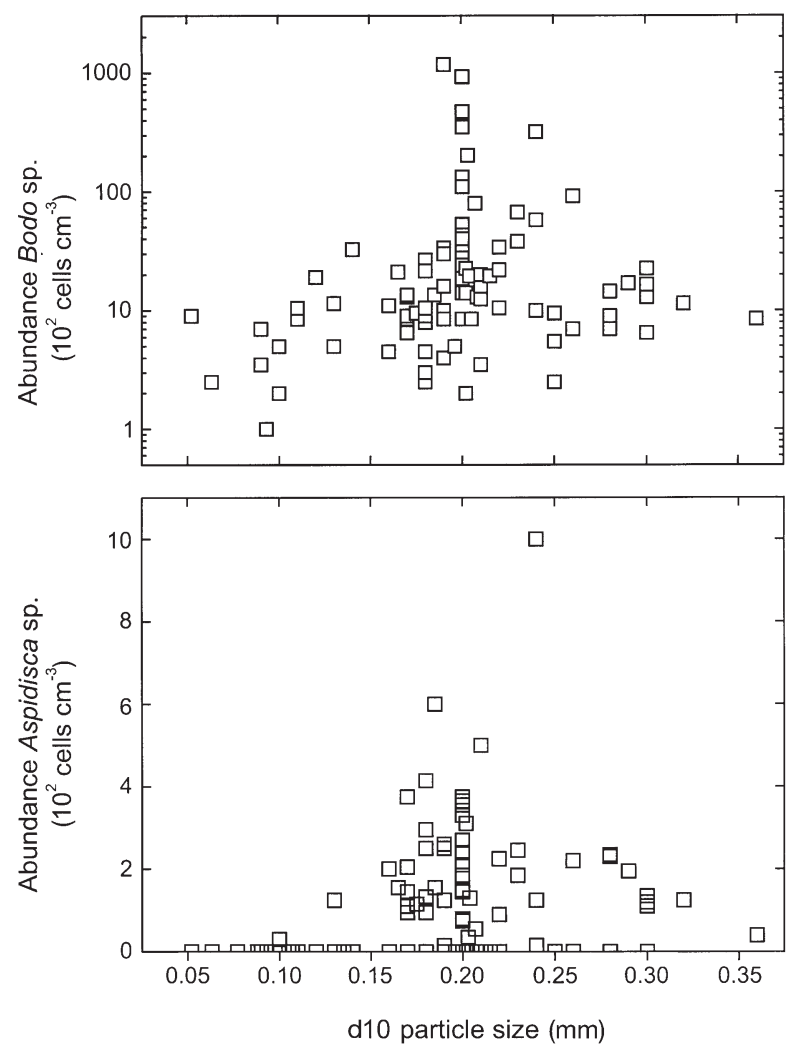

Fig. 4. Abundances of the dominant flagellate (Bodo) and ciliate (Aspidisca) genera at different d10 particle sizes of the sands of the River Spree

sediments, where contents of finer sediments were high, negative correlations with aerobic taxa and positive correlations with microaerophilic and anaerobic ciliates were found (Tables $1 \& 2$ ). Here, high contents of finer sediments may have limited DO trans-

Table 3. Published data on the abundance of flagellates and ciliates from sediments of various running waters. nts = natural sediments, is = incubated sediments, na = not available

\begin{tabular}{|c|c|c|c|}
\hline \multirow[t]{2}{*}{ Study } & \multirow[t]{2}{*}{ Site, sediment type } & \multicolumn{2}{|c|}{ Abundance (cells) } \\
\hline & & Flagellates & Ciliates \\
\hline Baldock \& Sleigh (1988) & $\begin{array}{l}\text { Itchen, silt and clay, and Ober water, fine sands, } \\
\text { surface sediments }(0.5 \mathrm{~cm}, \mathrm{nts})^{\mathrm{a}}\end{array}$ & $0-148000$ & $0-13000$ \\
\hline Bott \& Kaplan (1989) & $\begin{array}{l}\text { Saw Mill Spring and White Clay Creek, middle sands, } \\
\text { surface sediments }(1 \mathrm{~cm}, \mathrm{nts})^{\mathrm{b}}\end{array}$ & $\begin{array}{l}9-229 \times 10^{5} \\
6-104 \times 10^{5}\end{array}$ & $\begin{array}{l}5-33000 \\
5-37000\end{array}$ \\
\hline Schmid-Araya (1994) & Oberer Seebach, gravel, down to $40 \mathrm{~cm}$ depth (nts) ${ }^{\mathrm{a}}$ & $0-1250$ & $0-69$ \\
\hline Packroff \& Zwick (1998) & Breitenbach, fine sands, down to $10 \mathrm{~cm}$ depth (nts) ${ }^{\mathrm{a}}$ & na & $0-4500$ \\
\hline Eisenmann et al. (1998) & $\begin{array}{l}\text { Necker (3rd order), gravel, down to } 34 \mathrm{~cm} \mathrm{depth}^{\mathrm{a}} \\
\text { Necker (6th order), gravel, down to } 34 \mathrm{~cm} \text { depth (is) }\end{array}$ & $\begin{array}{c}0-89 \\
0-379\end{array}$ & $\begin{array}{l}21-115 \\
9-1098\end{array}$ \\
\hline $\begin{array}{l}\text { Present study } \\
\text { aData per } \mathrm{cm}^{3} \text { sediment } \\
{ }^{\mathrm{b}} \text { Data per } \mathrm{cm}^{2} \text { sediment } \mathrm{s}\end{array}$ & $\begin{array}{l}\text { Spree, middle sands, down to } 7 \mathrm{~cm} \text { depth }(\mathrm{nts})^{\mathrm{a}} \\
\text { face }\end{array}$ & $50-125700$ & $0-1870$ \\
\hline
\end{tabular}




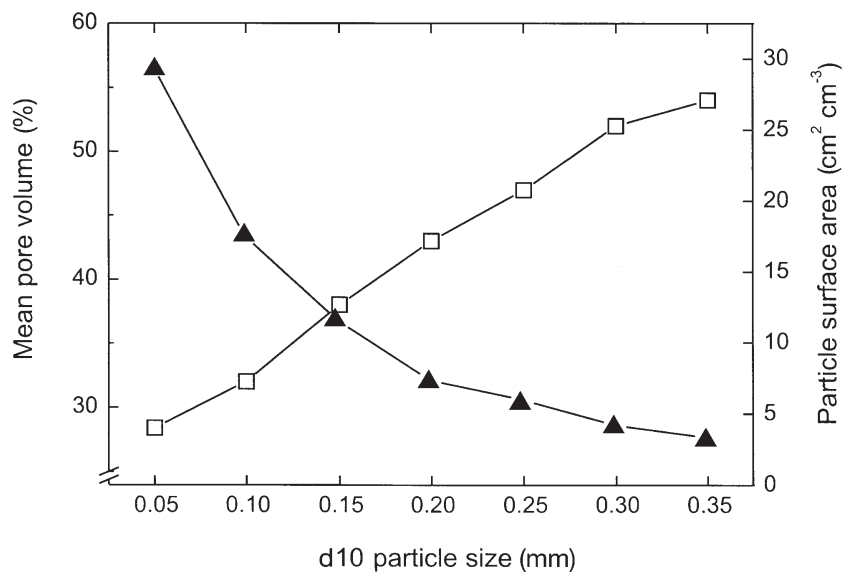

Fig. 5. Estimated pore volumes (ㅁ) and particle surface areas (४) at different d10 particle sizes of the sands of the River Spree

port into the sediments. Highest abundances of the most frequent and abundant flagellate and ciliate genera generally occurred at medium contents of finer sediment. We hypothesize that this was partially due to a trade-off between mean pore volume and particle surface area of the sediments. With a simple model, assuming that all sediment particles and pores were smooth and spherical, we estimated pore volumes and sediment surface areas for averaged particle size distributions with different d10 particle sizes in order to test our hypothesis (Fig. 5). Low pore volumes favor anaerobic conditions by reducing hydrologic exchange and diminish protozoan motility in the sediments (Fenchel 1987), whereas low particle surface areas provide little space for surface-oriented and surface-grazing protists. According to our data, this trade-off was optimally balanced at d10 particle sizes between 0.15 and $0.25 \mathrm{~mm}$, where we determined highest abundances of 2 surface-dwelling protozoan taxa. At the surface layer of the shifting sands, high current velocities, which bring about low contents of finer sediments but also cause mechanical disturbances to the protistan community, could have been another reason for low abundances associated with high d10 particle sizes.

Using the PCA, DO preferences of protists seemed to be an important functional property of protists affecting their taxonomical distribution in the sediments of the River Spree. Distribution patterns of aerobic, anaerobic and microaerophilic protists coincided with concentrations of DO in the pore water. This may provide indirect evidence that DO concentrations of these sediments influenced their protistan community structure, a phenomenon which is well-known from marine sediments (Fenchel 1987).

According to the PCA, direct or indirect light dependency of flagellate and ciliate taxa could potentially be another important factor controlling the spatial distribution of the community. This was mainly due to the fact that auto- and mixotrophic taxa and their predators occurred preferentially in the surface layer of the sediments. The maximal penetration depth of light into sandy sediments is 4 to 5 times the mean particle size (Schwoerbel 1964). Therefore, all light should be absorbed within the upper $2 \mathrm{~cm}$ of the sampled sediments.

In an early analysis of factors affecting the distribution of freshwater ciliates, Noland (1925) assumed that the nature and amount of available food is the most important factor. This hypothesis still appears to be warranted for many aquatic habitats (Taylor \& Sanders 1991). Eisenmann et al. (1999) also found strong correlations between flagellates and bacteria,

Table 4. Estimated grazing pressures (i.e. consumed bacterial biomass divided by bacterial production) of flagellates and ciliates on bacteria in the sediments of the River Spree. Consumed biomass assessed with grazing rates of 9 cells flagellate $\mathrm{h}^{-1}$ and 414 cells ciliate ${ }^{-1} \mathrm{~h}^{-1}$ at $10^{\circ} \mathrm{C}$ and 12 cells flagellate ${ }^{-1} \mathrm{~h}^{-1}$ and 2113 cells ciliate ${ }^{-1} \mathrm{~h}^{-1}$ at $20^{\circ} \mathrm{C}$, respectively (Bott \& Kaplan 1990 ), and mean seasonal abundances of bacterivorous flagellates and ciliates. $\mathrm{F}=$ flagellates, $\mathrm{C}=$ ciliates

\begin{tabular}{|c|c|c|c|c|}
\hline Scenario & $\begin{array}{l}\text { Protozoan abundance } \\
\text { (cells } \mathrm{cm}^{-3} \text { ) }\end{array}$ & $\begin{array}{c}\text { Consumed bacterial } \\
\text { biomass }\left(\mu \mathrm{g} \mathrm{C} \mathrm{h} \mathrm{h}^{-1} \mathrm{~cm}^{-3}\right)\end{array}$ & $\begin{array}{l}\text { Bacterial production } \\
\left(\mu \mathrm{g} \mathrm{C} \mathrm{h}^{-1} \mathrm{~cm}^{-3}\right)\end{array}$ & $\begin{array}{c}\text { Grazing pressure } \\
(\%)\end{array}$ \\
\hline Spring & $\begin{array}{l}\text { F: } 700 \\
\text { C: } 32.5\end{array}$ & $4.3 \times 10^{-4}$ & 2.4 & 0.02 \\
\hline Early summer & $\begin{array}{l}F: 2450 \\
\text { C: } 162.5\end{array}$ & $8.2 \times 10^{-3}$ & 3.0 & 0.28 \\
\hline Late summer & $\begin{array}{l}\text { F: } 2150 \\
\text { C: } 225\end{array}$ & $1.1 \times 10^{-2}$ & 3.0 & 0.36 \\
\hline $\begin{array}{l}\text { Sample with highest flagellate } \\
\text { abundance }\end{array}$ & $\begin{array}{l}\text { F: } 125700 \\
\quad C: 15\end{array}$ & $3.4 \times 10^{-2}$ & 3.4 & 1.01 \\
\hline Sample with highest ciliate abundance & $\begin{array}{l}\text { F: } 7200 \\
\text { C: } 1890\end{array}$ & $9.0 \times 10^{-2}$ & 5.4 & 1.67 \\
\hline
\end{tabular}


and ciliates and bacteria in sediments incubated in a prealpine gravel-bed river. We demonstrate that abundances of several taxonomic groups of bacterivorous protozoa in the natural sediments of the River Spree were correlated with bacterial numbers, whereas the abundances of other groups like autoand mixotrophic flagellates only weakly correlated with bacterial abundance. With our data, we cannot exclude the possibility that these correlations between protistan and bacterial abundances may be due to a common factor, like nutrient availability or current velocity, regulating both variables. Therefore, we cannot clearly say if bacterial abundance is a determinant or only a predictor of protistan abundance. However, as correlations between bacteria and bacterivorous protists were markedly stronger than between bacteria and other protistan groups, we assume that bacterial numbers do affect the abundance of bacterivorous protists.

In conclusion, the distribution of protistan taxa and numbers in the sediments of the River Spree were found to be affected by several factors. Bacterial numbers were important for the abundance of bacterivorous taxa. Ecophysiological factors, which are assumed to largely determine the large-scale distribution of protozoa (Fenchel 1987, Lee \& Patterson 1998), also appeared to be important for the vertical and lateral distribution of protists within the sediments of a river reach. DO and light penetration seemed to structure the flagellate and ciliate communities. Contents of finer sediments influenced the abundances of the most frequent and abundant flagellate and ciliate genera.

The knowledge we gained on the spatial and temporal distributions of various protistan taxa, whose trophic modes and prey spectra are well described, allows more exact estimates on potential grazing pressures than mere protistan numbers. We could therefore assess protozoan grazing pressure on bacterial production using our abundance data of bacterivorous taxa and published grazing rates (Table 4). These estimates suggest that flagellates and ciliates do not control bacterial growth in the sediments of the River Spree regardless of season. Even in samples with extraordinarily high protozoan abundances, grazing pressure was estimated to be 2 orders of magnitude too low to diminish bacterial numbers. Thus, we hypothesize that protozoan grazing of bacteria does not represent a major link in the carbon flow of the 6th order River Spree.

Acknowledgements. We thank M. Brunke, W. V. Sobczak and 3 anonymous reviewers for valuable comments on earlier drafts of the manuscript, and U. Grünert for her assistance in the field.

\section{LITERATURE CITED}

Arndt H, Dietrich D, Auer B, Cleven EJ, Gräfenhan T, Weitere M, Mylnikov AP (2000) Functional diversity of heterotrophic flagellates in aquatic ecosystems. In: Leadbeater BSC, Green JC (eds) The flagellates. Taylor \& Francis, London, p 240-268

Bak RPM, Nieuwland G (1989) Seasonal fluctuations in benthic protozoan populations at different depths in marine sediments. Neth J Sea Res 24:37-44

Baldock BM, Sleigh MA (1988) The ecology of benthic protozoa in rivers - seasonal variation in numerical abundance in fine sediments. Arch Hydrobiol 111:409-421

Berger H, Foissner W, Kohmann F (1997) Bestimmung und Ökologie der Mikrosaprobien nach DIN 38410. G Fischer, Stuttgart

Böhme M (1994) Release and consumption of oxygen by a phytoplankton dominated community of a eutrophic lowland river. Int Ver Theor Angew Limnol Verh 25: 1585-1589

Bott TL, Kaplan LA (1989) Densities of benthic protozoa and nematodes in a Piedmont stream. J N Am Benthol Soc 8: 187-196

Bott TL, Kaplan LA (1990) Potential for protozoan grazing of bacteria in streambed sediments. J N Am Benthol Soc 9: $336-345$

Brunke M, Fischer H (1999) Hyporheic bacteria-relationships to environmental gradients and invertebrates in a prealpine stream. Arch Hydrobiol 146:189-217

Caron DA (1987) Grazing of attached bacteria by heterotrophic microflagellates. Microb Ecol 13:203-218

Cleven EJ (1999) An improved method of taking cores in sandy sediments. Arch Hydrobiol 147:65-72

Dye AH (1979) Quantitative estimation of protozoa from sandy substrates. Estuar Coast Mar Sci 8:199-204

Eisenmann H, Traunspurger W, Meyer EI (1998) Community structure of selected micro- and meiobenthic organisms in sediment chambers from a prealpine river (Necker, Switzerland). In: Bretschko G, Helešic J (eds) Advances in river bottom ecology. Backhuys Publishers, Leiden, p 155-162

Eisenmann H, Burgherr P, Meyer EI (1999) Spatial and temporal heterogeneity of an epilithic streambed community in relation to the habitat templet. Can J Fish Aquat Sci 56: $1452-1460$

Epstein SS (1995) Simultaneous enumeration of protozoa and micrometazoa from marine sandy sediments. Aquat Microb Ecol 9:219-227

Fenchel T (1987) Ecology of protozoa. Science Technical Publishers, Madison

Findlay S, Sobczak WV (2000) Microbial communities in hyporheic sediments. In: Jones JB, Mulholland PJ (eds) Streams and ground waters. Academic Press, San Diego, p 287-306

Fischer H, Pusch M (2001) Comparison of bacterial production in sediments, epiphyton and the pelagic zone of a lowland river. Freshw Biol 46:1335-1348

Foissner W, Blatterer H, Berger H, Kohmann F (1991) Taxonomische und ökologische Revision der Ciliaten des Saprobiensystems - Band I: Cyrtophorida, Oligotrichida, Hypotrichia, Colpodea. Bayerisches Landesamt für Wasserwirtschaft, Munich

Foissner W, Berger H, Kohmann F (1992) Taxonomische und ökologische Revision der Ciliaten des Saprobiensystems-Band II: Peritrichia, Heterotrichida, Odontostomatida. Bayerisches Landesamt für Wasserwirtschaft, Munich 
Foissner W, Berger H, Blatterer H, Kohmann F (1995) Taxonomische und ökologische Revision der Ciliaten des Saprobiensystems-Band IV: Gymnostomatea, Loxodes, Suctoria. Bayerisches Landesamt für Wasserwirtschaft, Munich

Foissner W, Berger H, Schaumburg J (1999) Identification and ecology of limnetic plankton ciliates. Bayerisches Landesamt für Wasserwirtschaft, Munich

Hausmann K, Hülsmann N (1996) Protozoology. G Thieme Verlag, Stuttgart

Jongman RHG, TerBraak CJF, van Tongeren OFR (1995) Data analysis in community and landscape ecology. Cambridge University Press, Cambridge

Jürgens K, Pernthaler J, Schalla S, Amann R (1999) Morphological and compositional changes in a planktonic bacterial community in response to enhanced protozoan grazing. Appl Environ Microb 65:1241-1250

Kemp PF (1990) The fate of benthic bacterial production. Rev Aquat Sci 2:109-124

Köhler J (1994) Origin and succession of phytoplankton in a river-lake system (Spree, Germany). Hydrobiologia 289: $73-83$

Laybourn-Parry J, Parry J (2000) Flagellates and the microbial loop. In: Leadbeater BSC, Green JC (eds) The flagellates. Taylor \& Francis, London, p 216-239

Lee JJ, Leedale GF, Bradbury P (2000) An illustrated guide to the protozoa. Allen Press, Lawrence, KA

Lee WJ, Patterson DJ (1998) Diversity and geographic distribution of free-living heterotrophic flagellates-analysis by Primer. Protist 149:229-243

Meyer JL (1994) The microbial loop in flowing waters. Microb Ecol 28:195-199

Montagnes DJS, Lynn DH (1987) Agar embedding on cellulose filters - an improved method of mounting protists for protargol and Chatton-Lwoff staining. Trans Am Microsc Soc 106:183-186

Noland LE (1925) The factors affecting the distribution of freshwater ciliates. Ecology 6:437-452

Packroff G, Zwick P (1998) The ciliate fauna of an unpolluted German foothill stream, the Breitenbach, 2: Quantitative aspects of the ciliates (Ciliophora, Protozoa) in fine sediments. Eur J Protistol 34:436-445

Pomeroy LR (1974) The ocean's food web, a changing para-

Editorial responsibility: David Caron,

Los Angeles, California, USA digm. BioScience 24:499-504

Porter KG, Feig YS (1980) The use of DAPI for identifying and counting aquatic microflora. Limnol Oceanogr 25: 943-948

Pusch M, Fiebig D, Brettar I, Eisenmann H and 5 others (1998) The role of micro-organisms in the ecological connectivity of running waters. Freshw Biol 40:453-495

Ricci N (1989) Microhabitats of ciliates - specific adaptations to different substrates. Limnol Oceanogr 34:1089-1096

Schmid-Araya JM (1994) Temporal and spatial distribution of benthic microfauna in sediments of a gravel streambed. Limnol Oceanogr 39:1813-1821

Schwoerbel J (1964) Die Bedeutung des Hyporheals für die benthische Lebensgemeinschaft der Fließgewässer. Verh Int Ver Limnol 15:215-226

Schwoerbel J (1994) Methoden der Hydrobiologie, Süßwasserbiologie. G Fischer, Stuttgart

Skibbe O (1994) An improved quantitative protargol stain for ciliates and other planktonic protists. Arch Hydrobiol 130: 339-347

Sleigh MA (2000) Trophic strategies. In: Leadbeater BSC, Green JC (eds) The flagellates. Taylor \& Francis, London, p 147-165

Sleigh MA, Baldock BM, Baker JH (1992) Protozoan communities in chalk streams. Hydrobiologia 248:53-64

Sukhodolov A, Thiele M, Bungartz H (1998) Turbulence structure in a river reach with sand bed. Water Resour Res $34: 1317-1334$

Taylor WD, Sanders RW (1991) Protozoa. In: Thorp JH, Covich AP (eds) Ecology and classification of North American freshwater invertebrates. Academic Press, San Diego, p 37-93

Underwood AJ (1997) Experiments in ecology. Cambridge University Press, Cambridge

Wetzel RG (2001) Limnology-Lake and river ecosystems. Academic Press, San Diego

Wickham S, Gieseke A, Berninger UG (2000) Benthic ciliate identification and enumeration: an improved methodology and its application. Aquat Microbiol Ecol 22:79-91

Wright DA, Killham K, Glover LA, Prosser JI (1995) Role of pore size location in determining bacterial activity during predation by protozoa in soil. Appl Environ Microbiol 61: $3537-3543$

Submitted: May 27, 2002; Accepted: October 4, 2002

Proofs received from author(s): January 31, 2003 